\title{
Maternal Preferences for Vitamin D Supplementation in Breastfed Infants
}

Puja J. Umaretiya, $M D^{1,3}$

Sara S. Oberbelman, $M D^{2}$

Elizabeth W. Cozine, $M D^{2}$

Julie A. Maxson, BA ${ }^{2}$

Stephanie M. Quigg ${ }^{2}$

Tom D. Thacher, $M D^{2}$

'Mayo Medical School, Rochester, Minnesota

${ }^{2}$ Department of Family Medicine, Mayo Clinic, Rochester, Minnesota

${ }^{3}$ Boston Children's Hospital, Boston, Massachusetts
Conflicts of interest: Dr Thacher is a consultant for Biomedical Systems, Inc, and has received a speaking bonorarium from Sandoz. The other authors report none.

\section{CORRESPONDING AUTHOR}

Tom D. Thacher, MD

Department of Family Medicine

Mayo Clinic Rochester

200 First St SW

Rochester, MN 55905

thacher.thomas@mayo.edu

\begin{abstract}
Daily vitamin $\mathrm{D}$ supplementation is recommended for breastfed infants, but alternative methods include enriching breast milk with vitamin $D$ through maternal supplementation or intermittent high-dose vitamin D. We determined maternal preferences for vitamin D supplementation in 140 mothers with exclusively breastfed infants, and 44 who used both breast and formula milk. Only 101 (55\%) supplemented their infants with vitamin D. One hundred sixty (88\%) preferred supplementing themselves rather than their infants, and 102 (57\%) preferred daily to monthly supplementation. Safety was most important in choosing a method of supplementation. Taking maternal preferences into consideration may improve adequate intakes of vitamin $\mathrm{D}$ in breastfed infants.
\end{abstract}

Ann Fam Med 2017;15:68-70. https://doi.org/10.1370/afm.2016.

\section{INTRODUCTION}

$\mathrm{V}$ itamin D deficiency has become a global public health concern Nutritional rickets is the most established consequence, and an increasing incidence of rickets has been observed in developed countries. ${ }^{1,2}$ In one study up to $18 \%$ of US children were vitamin D deficient, and $1 \%$ had severe deficiency. ${ }^{3}$

Breastfed infants are vulnerable to vitamin D deficiency because of the low concentration of vitamin D in breast milk. The American Academy of Pediatrics (AAP) recommends supplementation of breastfed, partially breastfed, and bottle-fed infants with vitamin D at $400 \mathrm{IU} / \mathrm{d}$, beginning in the first few days of life. ${ }^{4}$ Adherence to this recommendation, however, is poor. ${ }^{5}$

Several studies have explored alternative methods of supplementation. Breast milk can be enriched with vitamin D through daily or intermittent high-dose maternal supplementation to meet infants' vitamin $\mathrm{D}$ requirements. ${ }^{6,7}$ Alternatively, oral vitamin D, 50,000 IU every 2 months, can be given to healthy infants with routine vaccinations to prevent vitamin $\mathrm{D}$ deficiency. ${ }^{8}$

Little is known about maternal preferences for different methods of vitamin D supplementation. Our aim was to assess maternal practices and preferences for vitamin D supplementation of their infants in primary care.

\section{METHODS}

Mothers seeking care with infants for either 2-month or 4-month wellchild visits were surveyed regarding vitamin D supplementation. Eligible mothers were aged 18 years and older, spoke English, and had an infant aged between 6 weeks and 5 months that was receiving primary care at Mayo Clinic in Rochester, Minnesota. Practices included 1 urban site, 2 suburban sites, and 1 rural site.

We collected data regarding infant feeding practices, vitamin D supplementation, and maternal preferences for the mode of vitamin D supplementation. Response options included either supplementation of the baby or mother with vitamin D and either daily or monthly high-dose 
Table 1. Maternal and Infant Characteristics ( $n=184)$

\begin{tabular}{lc}
\hline Characteristic & Value \\
\hline Age of infant, No. (\%) & $11(6.0)$ \\
$<2$ mo & $112(60.9)$ \\
$2-3.9$ mo & $61(33.2)$ \\
$4-5.9$ mo & \\
Race, No. (\%) & $175(95.1)$ \\
White & $9(4.9)$ \\
Asian & $5(2.7)$ \\
Hispanic & $3(1.6)$ \\
Black or African American & $2(1.1)$ \\
American Indian/Alaskan Native & $73(40.1)$ \\
First-time mothers, No. (\%) & $2(1-8)$ \\
Number of children, median (range) & \\
Practice location, No. (\%) & $108(58.7)$ \\
Urban & $70(38.0)$ \\
Suburban & $7(3.8)$ \\
Rural & \\
Feeding characteristics & $140(76.1)$ \\
Breast milk only, No. (\%) & $44(23.9)$ \\
Breast milk and formula, No. (\%) & $101(55.2)$ \\
Supplementing infant with vitamin D, No. (\%) & $2(0-17)$ \\
Age when infant began supplementation, median & \\
(range), wk & $138(75.8)$ \\
Mother taking supplement with vitamin D, No. (\%) & \\
\hline
\end{tabular}

vitamin D. Mothers rated the importance of convenience, safety, being most natural, and cost in choosing between options for vitamin D supplementation.

The survey questionnaires were distributed to the mothers in the urban site in October 2013. Questionnaires were mailed to mothers at all 4 sites in November and December 2013. A second mailing was sent to nonrespondents 30 days later. The questionnaires had no patient-identifying information and included instructions not to complete it twice.

The Mayo Clinic Institution Review Board approved the study.

\section{RESULTS}

A total of 601 questionnaires were mailed, 438 nonrespondents were sent a second mailing, and $31 \mathrm{com}-$ pleted the survey during well-child visits. In all, 236 mothers completed the survey. We report results for the 140 mothers with exclusively breastfed infants and 44 who used both breast and formula milk. Characteristics of the mothers and their infants are shown in Table 1.

Of the mothers, $138(76 \%)$ were taking a multivitamin with vitamin D. Only 101 (55\%) had supplemented their infants with vitamin $\mathrm{D}$ in the preceding week (median $5 \mathrm{~d} / \mathrm{wk}$ ), and 77 infants (42\%) received the $400 \mathrm{IU}$ recommended. The proportion of infants receiving supplementation did not vary by age $(P=.46)$. A total of $134(73 \%)$ reported that their clinician had recommended infant vitamin $D$ supplementation, and these mothers were more likely to supplement their infants with vitamin $\mathrm{D}(\mathrm{OR}=8.3$; 95\% CI, 3.8-18). The 11 nonwhite mothers (4.9\%) were more likely to supplement infants with vitamin $\mathrm{D}$ than white mothers $(P=.04)$. Mothers rated ease of administering vitamin $D$ supplementation as 4 on a scale of 1 to 5 (with 5 being easiest), but 6 of 105 respondents (5.7\%) found administration burdensome (rated 1 or 2).

The great majority of breastfeeding mothers (88.4\%) preferred supplementing themselves rather than their infants with vitamin D. Most expressed a desire for a daily supplementation (57\%) compared with monthly supplementation. In rating the importance of factors informing their choices, mothers rated safety highest, and cost was rated lowest. First-time mothers and those who had additional children had similar preferences and value ratings.

Regarding reasons for not supplementing infants with vitamin D (Table 2), many mothers indicated lack of knowledge about supplementation, some believed that breast milk provided infants with adequate vitamin $D$, and others chose not to supplement because of inconvenience or their infant's apparent dislike of the supplement.

\section{Table 2. Maternal Reasons for Not} Supplementing Infants With Vitamin D

\begin{tabular}{|c|c|}
\hline Themes & Quotes \\
\hline \multirow{3}{*}{$\begin{array}{l}\text { Lack of knowl- } \\
\text { edge about } \\
\text { supplementation }\end{array}$} & "I didn't know I should" \\
\hline & "Too young - will start soon" \\
\hline & $\begin{array}{l}\text { "Never even knew vitamin D supplementa- } \\
\text { tion was needed" }\end{array}$ \\
\hline \multirow{4}{*}{$\begin{array}{l}\text { Assumption that } \\
\text { fortified milk pro- } \\
\text { vides infant with } \\
\text { needed vitamin D }\end{array}$} & $\begin{array}{l}\text { "I gave vitamin D supplement when she was } \\
\text { breast milk-fed, provider told us to discon- } \\
\text { tinue when formula started" }\end{array}$ \\
\hline & $\begin{array}{l}\text { "My baby went to exclusive soy formula } \\
\text { at } 2 \text { months old, which has vitamin D } \\
\text { supplement" }\end{array}$ \\
\hline & $\begin{array}{l}\text { "Baby formula has all that is needed and } \\
\text { recommended" }\end{array}$ \\
\hline & $\begin{array}{l}\text { "Stopped giving it when I stopped nursing } \\
\text { and started to give formula" }\end{array}$ \\
\hline \multirow{2}{*}{$\begin{array}{l}\text { Assumption that } \\
\text { breast milk pro- } \\
\text { vides infant with } \\
\text { needed nutrition }\end{array}$} & $\begin{array}{l}\text { "Find it hard to believe the whole popula- } \\
\text { tion is so deficient in Vitamin D, especially } \\
\text { in breast milk" }\end{array}$ \\
\hline & $\begin{array}{l}\text { "I feel like my breast milk was designed by } \\
\text { God to give my baby what she needs. } \\
\text { Babies have been fine and healthy } \\
\text { without Vitamin D supplementation for } \\
\text { generations" }\end{array}$ \\
\hline \multirow{2}{*}{$\begin{array}{l}\text { Inconvenience/ } \\
\text { Dislike }\end{array}$} & "It causes her to spit up" \\
\hline & $\begin{array}{l}\text { "I forget to because she doesn't take it well } \\
\text { and doesn't seem to like the taste" }\end{array}$ \\
\hline
\end{tabular}




\section{DISCUSSION}

Less than one-half the infants in this study met the AAP recommendation for vitamin D supplementation of breastfed and bottle-fed infants. More mothers took a vitamin D supplement than provided their infants with a supplement, and a minority of breastfeeding mothers adequately supplemented their infants.

Most breastfeeding mothers preferred supplementing themselves rather than their infants, and most preferred daily rather than monthly supplementation. Advantages of maternal rather than infant supplementation include increased ease of administration, simultaneous mother and infant supplementation, and avoidance of potential toxicity to the infant from dosing errors. ${ }^{9,10}$

High-dose maternal vitamin D supplementation (4000-6400 IU/d or a single monthly dose of 150,000 IU) can sufficiently enrich breast milk in nursing mothers, preventing vitamin D deficiency in their infants without evident toxicity. ${ }^{6,7}$ Mothers take a prenatal vitamin after delivery, so additional vitamin $\mathrm{D}$ could be incorporated in the maternal supplementation routine.

Our findings are limited by our study population of predominantly white mothers and might not apply to populations that are nonwhite or at a greater risk of vitamin D deficiency. Additionally, mothers who completed the questionnaire may have practices and preferences that are different from those of nonrespondents.

Promotion of breastfeeding as a complete nutritional source could be facilitated by providing adequate maternal vitamin D supplementation to breastfeeding mothers. Maternal choice of mode of supplementation may help ensure adequate vitamin D status for infants.

To read or post commentaries in response to this article, see it online at http://www.annfammed.org/content/15/1/68.

Key words: infant; breast feeding; decision making, shared; vitamin D deficiency, prevention \& control

Submitted May 5, 2016; submitted, revised, September 1, 2016; accepted October 16, 2016.
Funding support: This study was supported by Mayo Clinic CTSA through grant number UL1 TR000135 from the National Center for Advancing Translational Sciences (NCATS), a component of the NIH.

Disclaimer: The content is solely the responsibility of the authors and does not necessarily represent the official views of the NIH.

Previous presentation: Posters were presented at the North American Primary Care Research Group Annual Meeting, October 24-28, 2015, Cancun, Mexico; and the Seoul International Congress of Endocrinology and Metabolism, April 30-May 3, 2016, Seoul, Korea.

\section{References}

1. Munns CF, Shaw N, Kiely M, et al. Global Consensus Recommendations on Prevention and Management of Nutritional Rickets. J Clin Endocrinol Metab. 2016;101(2):394-415.

2. Thacher TD, Fischer PR, Tebben PJ, et al. Increasing incidence of nutritional rickets: a population-based study in Olmsted County, Minnesota. Mayo Clin Proc. 2013;88(2):176-183.

3. Mansbach JM, Ginde AA, Camargo CA Jr. Serum 25-hydroxyvitamin $D$ levels among US children aged 1 to 11 years: do children need more vitamin D? Pediatrics. 2009;124(5):1404-1410.

4. Wagner $\mathrm{CL}$, Greer FR; American Academy of Pediatrics Section on Breastfeeding; American Academy of Pediatrics Committee on Nutrition. Prevention of rickets and vitamin D deficiency in infants, children, and adolescents. Pediatrics. 2008;122(5):1142-1152.

5. Perrine CG, Sharma AJ, Jefferds ME, Serdula MK, Scanlon KS. Adherence to vitamin D recommendations among US infants. Pediatrics. 2010;125(4):627-632.

6. Oberhelman SS, Meekins ME, Fischer PR, et al. Maternal vitamin D supplementation to improve the vitamin D status of breast-fed infants: a randomized controlled trial. Mayo Clin Proc. 2013;88(12): 1378-1387.

7. Hollis BW, Wagner $\mathrm{CL}$, Howard $\mathrm{CR}$, et al. Maternal versus infant vitamin $\mathrm{D}$ supplementation during lactation: a randomized controlled trial. Pediatrics. 2015;136(4):625-634.

8. Shakiba M, Sadr S, Nefei Z, Mozaffari-Khosravi H, Lotfi MH, Bemanian $\mathrm{MH}$. Combination of bolus dose vitamin $\mathrm{D}$ with routine vaccination in infants: a randomised trial. Singapore Med J. 2010;51(5): 440-445.

9. Ketha $H$, Wadams $H$, Lteif $A$, Singh RJ. latrogenic vitamin D toxicity in an infant-a case report and review of literature. J Steroid Biochem Mol Biol. 2015;148:14-18.

10. Barrueto F Jr, Wang-Flores HH, Howland MA, Hoffman RS, Nelson LS. Acute vitamin D intoxication in a child. Pediatrics. 2005;116(3): e453-e456. 